\title{
Does Monetary Compensation During Railway Construction Make Household Better-Off?
}

\author{
By \\ Janathin Saraswati, Dijan Rahajuni, Muhammad Farid Alfarisy*) \\ Faculty of Economics and Business, Universitas Jenderal Soedirman \\ ${ }^{*}$ Corresponding Author: m.farid.alfarisy@gmail.com
}

Submission: March 26, 2021; Accepted: May 17, 2021

\begin{abstract}
The main aim of this study is to investigate the implication of overpass and double line railway construction conducted by PT Kereta Api Indonesia (KAI) on changes in income generating asset and the level of welfare in the community. We surveyed 28 households in Gambarsari Village, District Kebasen as affected communities who received monetary compensation from PT KAI. Comparisons between pre and post construction implication on the income generating asset of this group were made using Wilcoxon test. To compare whether the affected community become wealthier after receiving compensation, a ratio of per capita income to regional decent standard of living or Kualitas Hidup Layak (KHL) was used. The results of this study find that monetary compensation given by PT KAI has no significant impact on income generating asset. This result may be explained by the fact that instead of spending the received compensation on investment purposes such as buying a new land or kiosk, they use it for consumption purposes such as house makeover and renovation. Another important finding was that this study did not show any significant increase in household welfare level after the monetary compensation was given. A possible explanation to this result is the fact that most of affected household are elderly people who prefer to spend the compensated money for consumption rather than new income generating asset.
\end{abstract}

Keywords: Impact Evaluation, Overpass and Double Track Railway Construction, Land Acquisition

ABSTRAK

Tujuan penelitian ini adalah menginvestigasi dampak dari pembangunan overpass dan double line yang dilakukan oleh PT Kereta Api Indonesia (KAl) terhadap perubahan pendapatan atas asset dan terhadap perubahan tingkat kesejahteraan masyarakat. Kami telah mensurvei sebanyak 28 rumah tangga yang menerima kompensiasi dari PT. KAl. di Desa Gambarsari, Kecamatan Kebasen sebagai masyarakat terdampk. Untuk mengetahui dampak terhadap perubahan atas asset, penelitian ini menggunakan alat analaisis Uji Wilcoxon. Sementara untuk mengetahui perubahan tingkat kesejahteraan masyarakat setelah menerima kompensasi adalah dengan membandingkan rata-rata pendapatan keluarga dengan KHL. Hasil penelitian menunjukkan bahwa kompensasi yang diberikan oleh PT KAl tidak berdampak signifikan terhadap perubahan tingkat pendapatan rumah tangga terdampak. Hasil ini dikarenakan uang kompensasi tersebut lebih banyak digunakan untuk tujuan konsumsi seperti menggunakannya untuk merenovasi rumah daripada untuk melakukan investasi pembelian lahan ataupun kios. Temuan lain pada penelitian ini adalah uang kompensasi yang diterima rumah tangga ternyata tidak membuat mereka menjadi lebih sejahtera. Salah satu penjelasan yang memungkinkan dari temuan ini adalah fakta bahwa sebagian rumah tangga terdampak adalah para 
orang tua yang usianya sudah tidak lagi produktif sehingga lebih memilih membelanjakannya daripada untuk menginvestasikannya.

Kata Kunci: Analisis Dampak, Pembangunan Overpass dan Double Track, Pembebasan Lahan.

\section{INTRODUCTION}

In Indonesian economy, one of the main characteristics is that State Owned Enterprise (SOE) plays an important role. In term of asset value, sales and profit, SOEs in Indonesia were ranked among the biggest companie in the country. So does railway construction in Indonesia, it is operated by SOEs which specialized in different fields. For instance, PT. WIKA is responsible for railway construction and PT. Kereta Api Indonesia (KAl) is responsible for railways operation. In this position, Indonesian Ministry of transportation acts as regulator and policy formulation.

Infrastructure for transportation plays important role in Indonesian economy. As Silondae et al. (2016) holds the view that it would be easier to develop areas with high economic potentials if transportation were properly developed. The past seven years has witnessed the rapid development of infrastructure for transportation by Indonesian government in many areas. According to the Indonesian Ministry of transportation report in 2018, there are 10 new airports have been built, 65 bus station have been rehabilitated, 125 seaports location (both for passenger and non-commercial use) have been established, and 45 railway construction projects have been executed during 2014 to 2018. Along with this growth in infrastructure projects, our research is concerned with the establishment of railway line by the government.

A number of projects in order to improve railway networks were under construction or in the planning stage. Since 2015 , there are as long as $1,025 \mathrm{~km}$ long railway line had been established by Indonesian government (see Table 1). As seen on the table, there has been a gradual increase in the number of the railway line construction since 2015 from $89.91 \mathrm{~km}$ long then stretched to $1,025.61 \mathrm{~km}$ railway line in 2019.

Table 1. New Railway Line Construction in Indonesia

\begin{tabular}{lcccccc}
\hline & Unit & 2015 & 2016 & 2017 & 2018 & 2019 \\
\hline Construction of new railway line & $\mathrm{km}$ & 89.91 & 184.73 & 373.29 & 744.05 & $1,025.61$ \\
\hline
\end{tabular}

Source: Indonesia Ministry of Transportation (2019)

The need to strengthening connectivity and reducing logistic cost has initiated Indonesian government to upgrade the trans java (northern and southern) single-track line railroads into doubletrack line. While $727 \mathrm{~km}$ long northern route is completed in 2014, along with this construction, however, there is increasing concern over the project that has fallen far behind schedule in southern route of Java due to complicated negotiation in acquiring plotted land.

Although land acquisition is inseparable activity in the development of infrastructure (Rianto, 2011), during large scale double-track railway line network construction across Java, land acquisition become a notorious problem that frequently delaying project. One of the problems is as argued by Shankar (2018), that in fact, land acquisition for railways was compulsory and the landowner could only negotiate the term (such as land price) and not the acquisition of land itself. However, after the Indonesian House of Representative passed the Act law No. 2/2012 and later supported by Presidential Decree No.71/2012 it brings a great deal for landowner and investors during acquisition in infrastructure project. Under the act, the land will be valued by independent appraisal and monetary compensation will be based on market price and also take into account its perceived resulting loss due to giving up the land.

One of the important projects of railway construction during 2019 was the 27 thousand $\mathrm{km}$ long double-track line connecting Purwokerto and Kroya (as part of southern Java railway networks). This 
construction could shorten travel time and is expected to rise freight capacity between cities. According to Transportation Statistics published by Directorate General of Railway as part of the Indonesia Ministry of Transportation, it shows that the 5-year railway construction project already had invited 413 million passengers in Java during 2018. Or on average, the growth of annual production of railway passengers is 11.26 percent while for freight transport, the growth of annual production is 6.71 percent.

The earliest stage of construction connecting Purwokerto-Kroya begins with the construction of overpass double-line railway track. This construction was located in Gambarsari Village, District Kebasen where farmland and houses were already established. As a consequence, the people of Gambarsari Village, District Kebasen as affected communities received monetary compensation from government or in this case PT KAI as operator of the project. Nevertheless, although the affected community has received compensation, it also brings socioeconomic implication to the community.

The acquisition of land leads to changes in economic and social condition of the affected community, and off course it also depends on the ability of landowner to manage the compensation from the government and the ability to adapt with their new environment. Land acquisition can be detrimental to local livelihood. Forcible land acquisition not only causes shift in livelihood of community in Gambarsari Village but also their residential complex around the project.

Several studies investigating the impact of land acquisition on socioeconomic condition have been carried out, such as Matufany et al. (2021) who find that the construction of Kertajati International Airport has reduced on-farm income of farm households while increasing off-farm employment leading to insignificant difference in farm household income before and after the land acquisition. Nath and Raganata (2020) estimate that Jakarta-Bandung high speed railway project will cause two thousand traditional job loss around the track. Dewitasari (2015) who investigated the socioeconomic impact of Surabya-Mojokerto toll-road construction found several implications. It mentions that after land acquisition the social bond between the member of communities is weakened due to settlement movement, the project also shifts the community livelihood from farmers into small businessman, and create variation in community welfare because of the difference in ability to adapt with the new environment.

This study sets out to investigate the impact of overpass and double line railway construction conducted by PT Kereta Api Indonesia (KAI) on changes in income generating asset and the level of welfare in the community of Gambarsari Village, District Kebasen as affected communities who received monetary compensation from PT KAI. Previous studies in the field of impact evaluation;) particularly who investigate the implication of land acquisition on household's socioeconomic condition (Obidzinski et.al., 2012; Nguyen et.al., 2019; Matufany et al., 2021) have only focused on change in household income. Rather than using the change in average income, our study specifically focused on change in income generating asset. It means when household receive money, it is treated in form of compensation due to loss in productive asset and not in form of additional income. Therefore, by using this method our research expects to give more clear information and perspective about the impact of land acquisition and to give contribution to the impact evaluation research.

\section{METHODS}

In order to obtain clear information on an issue being investigated, census method is used in this research. We surveyed 28 households in Gambarsari Village, District Kebasen. The subjects were selected on the basis that they were identified as the affected households who received monetary compensation from PT KAI due to acquisition of land during railway construction.

Our research, according to Sugiyono (2017:50), is a comparative study within which we compare two paired samples or in our case two paired population. To know whether there is any difference between pre and post railway construction implication on the income generating asset of concerned households, we use Wilcoxon test as the analytical tool.

It is necessary here to clarify exactly what is meant by household's income generating asset. The broad term of household income in some research are sometimes defined as the total amount of 
money earned by household members, including wages, salaries, investment return, and payments. However, there are certain drawbacks when using measurement. One of these is that when household received compensation during land acquisition, then it will add to total income and make household's income higher. So, doing impact analysis based on this criterion can generate ambiguous conclusion.

An alternative method is by using the income generating asset. When household receive money, it is treated in form of compensation due to loss in productive asset such as farmlands, kiosk, workshop, fish pond, and house. Previously, these assets generate income to households and when these assets are evicted, household will face opportunity loss. By comparing the generated income of these assets and their use of compensated money, this research expects to give clear information about the impact of land acquisition on household's income.

As mentioned, that our research is concerned to compare the pre and post implication of railway construction, then our first step for preliminary analysis is to identify whether the data being analyzed are normally distributed or not. If the data are normally distributed, we use the parametric method such as paired t-test or z-test, otherwise non-parametric method like Wilcoxon test will be used.

Two components of normality test (skewness and kurtosis) are used in order to compute the zvalues. Then we run statistical test to determine whether the data were normally distributed or not using the $z$ value of skewness and kurtosis (Ghozali, 2016:28).

$$
\begin{aligned}
& \text { Z-Skew }=\frac{S-0}{\sqrt{6 / N}} \\
& \text { Z-Kurt }=\frac{K-0}{\sqrt{24 / N}}
\end{aligned}
$$

From the formula, $\mathrm{S}$ denotes skewness value, $\mathrm{N}$ for number of observations, and $\mathrm{K}$ is kurtosis. Data is identified as normally distributed when the value of Z-Skew and Z-Kurt exceed the critical value of $z$ (exceed 1.96 at $\alpha=5$ percent).

We assumed that our data are not normally distributed. So non-parametric approach to compare the difference in household's income generating asset after acquisition of land for railway construction is considered. We use Wilcoxon test as non-parametric test on our two correlated samples to determine the real difference between pair data taken from one related sample (Kadir, 2016: 505). The Wilcoxon test used is as follows (Sugiyono, 2017: 333):

$$
\mathrm{Z}=\frac{T-\frac{n(n+1)}{4}}{\sqrt{\frac{n(n+1)(2 n+1)}{24}}}
$$

\section{Where $Z$ is value of $z, T$ is number of levels/ranks and $n$ is number of observations}

To investigate whether the affected households become wealthier after receiving compensation, a ratio of per capita income to regional decent standard of living or Kualitas Hidup Layak (KHL) is used. Per capita income in our research is reflected in household income percapita which is measured according to procedure used by Wauran (2012), Yughi (2018) and Rizal et.al. (2018), that is adding up the total amount of household income and divided by the number of household members.

$$
\begin{gathered}
\text { Per capita income }=\frac{T P R N}{\text { number of household members }} \\
T P R N=P N+P A N+P I N
\end{gathered}
$$

Total household income (TPRN) equals to the amount of husband income (PN), plus amount of wife income (PAN), and income from other sources (PIN). In order to identify whether the households 
become wealthier after receiving compensation, we use ratio of per capita income to regional decent standard of living or Kualitas Hidup Layak (KHL).

According to Ministry of Manpower Regulation number 21/2016, KHL measures the minimum monthly amount of money needed to fulfill basic needs including consumption on education, personal well-being, transportation and communication. The information of $\mathrm{KHL}$ is published by national and regional government statistic agency BPS or Badan Pusat Statistik. Our research uses regional KHL that applies in Banyumas Regency. Because land acquisition was conducted in two different years of 2006 and 2016, then we use KHL in both years as pre railway construction period. For period reflecting the post railway construction, we use $\mathrm{KHL}$ in 2021 . So, in order to determine the household economic condition after railway construction we use ratio as follow:

$$
\text { Household welfare condition }=\frac{\text { income per capita }}{K H L}
$$

If the ratio of per capita income to $\mathrm{KHL}$ is larger than one, then household is said to be prosperous and wealthy. However, if the ratio of per capita income to KHL is smaller than one, it means otherwise.

\section{RESULTS AND DISCUSSIONS}

\section{Change in Household per Capita Income}

Our first objective in this research is to find whether there is any difference in the average of household income generating asset after railway construction. Our first step is to identify whether the data being analyzed are normally distributed. The results of the normality test can be seen at Table 2 .

Table 2 Normality Test

\begin{tabular}{|c|c|c|c|c|c|}
\hline \multirow{2}{*}{ Sample Criterion } & \multirow[t]{2}{*}{$\mathrm{N}$} & \multicolumn{2}{|c|}{ Skewness (S) } & \multicolumn{2}{|c|}{ Kurtosis (K) } \\
\hline & & Statistic & Std. Error & Statistic & Std. Error \\
\hline \multirow{4}{*}{$\begin{array}{l}\text { Before land acquisition } \\
\text { Value of Z Skewness } \\
\text { and Kurtosis }\end{array}$} & 28 & 1.947 & 0.441 & 2.677 & \multirow[t]{4}{*}{0.858} \\
\hline & & 1.94 & & 2,67 & \\
\hline & 28 & 6 & & 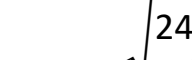 & \\
\hline & & Zskew $=4.20$ & & Zkurt $=2.89$ & \\
\hline \multirow{4}{*}{$\begin{array}{l}\text { After land acquisition } \\
\text { Value of Z Skewness } \\
\text { and Kurtosis }\end{array}$} & 28 & 1.680 & \multirow[t]{4}{*}{0.441} & 1.412 & \multirow{4}{*}{$\begin{array}{l}-0 \\
28\end{array}$} \\
\hline & & 1.68 & & \multirow{3}{*}{$\begin{array}{l}\text { Zkurt }=\frac{1.412-(}{\sqrt{24 / 2 \varepsilon}} \\
\text { Zkurt }=1.525\end{array}$} & \\
\hline & 28 & & & & \\
\hline & & Zskew $=3.62$ & & & \\
\hline
\end{tabular}

Based on Table 2, for sample criterion indicating before land acquisition, it shows that the computed value of $Z$ skewness and $Z$ kurtosis exceed the 5 percent critical value (1.96). So, the hypothesis that the data are normally distributed is rejected. For sample criterion indicating after land acquisition, it shows that the computed value of $Z$ Skewness is also greater than 5 percent critical value, indicating the data is not normally distributed. However, for computed value of $Z$ kurtosis, its value is smaller than 1.96 critical value, indicating the data are normally distributed. In normality distribution, skewness has to do with the symmetry of the distribution (the location of mean), while kurtosis has to do with the peakedness of a distribution (Tabachnick and Fidell, 2013:113). Despite our data after land acquisition criterion shows that the mean value of the data is neither too peaked with short, thick tail nor too flat, yet the mean is not in the center of distribution. So, in this regard we consider the data after land acquisition are also not normally distributed. 
Regarding the data sample that are not normally distributed then we use non-parametric analysis to test the hypothesis that household's income generating asset after acquisition of land for railway construction is higher. The result of Wilcoxon test is presented at Table 4.

Table 4. Wilcoxon Test Results Income on Assets Before and After Construction Overpass and Double Track

\begin{tabular}{|c|c|c|c|c|c|c|}
\hline \multicolumn{2}{|c|}{ Description } & $N$ & $\begin{array}{l}\text { Mean } \\
\text { Rank }\end{array}$ & Sum of Ranks & Z & $\begin{array}{l}\text { Asymp. Sig. } \\
\text { (2-tailed) }\end{array}$ \\
\hline \multirow{4}{*}{$\begin{array}{l}\text { Difference in household } \\
\text { income percapita before } \\
\text { and after railway } \\
\text { construction }\end{array}$} & Negative Ranks & 9 & 8,50 & 76,50 & \multirow{4}{*}{0,000} & \multirow{4}{*}{1,000} \\
\hline & Positive Ranks & 8 & 9,56 & 76,50 & & \\
\hline & Ties & 11 & & & & \\
\hline & Total & 28 & & & & \\
\hline
\end{tabular}

Because the computed $z$ value $(0.00)$ is less than $|1,96|$ the null hypothesis is not rejected. It means that the data show no significant difference in the household's per capita income derived from asset after they receive compensation from land acquisition. This result differs from Kayupa (2015) and Wang et.al (2019) who found that household was made better-off after land acquisition during infrastructure development project. A possible explanation for this might be that previous research emphasized only on household income. Household total income tends to rise when they received monetary compensation. Yet, our study focused on the income generating asset. So, when household receive money, it is treated in form of compensation due to loss in productive asset.

Our result shows there is no difference in income from assets used for economic activities before and after the construction of overpass and double tracks railway. The result may be explained by the fact that most of the compensated money received by household is not used for buying new assets.

Table 5. Respondent's Residential Area

\begin{tabular}{|c|c|c|c|c|c|}
\hline \multirow[b]{2}{*}{ No } & \multirow{2}{*}{$\begin{array}{c}\text { Residential Area } \\
\left(\mathrm{m}^{2}\right)\end{array}$} & \multicolumn{2}{|c|}{ Before } & \multicolumn{2}{|c|}{ After } \\
\hline & & $\begin{array}{l}\text { Number of } \\
\text { Household }\end{array}$ & $\begin{array}{l}\text { Percentage } \\
\text { (\%) }\end{array}$ & $\begin{array}{l}\text { Number of } \\
\text { Household }\end{array}$ & Percentage (\%) \\
\hline 1 & $56-200$ & 9 & 32.14 & 11 & 39.29 \\
\hline 2 & $201-345$ & 13 & 46.43 & 6 & 21.43 \\
\hline 3 & $346-490$ & 3 & 10.71 & 6 & 21.43 \\
\hline 4 & $491-635$ & 2 & 7.14 & 3 & 10.71 \\
\hline 5 & $636-780$ & 1 & 3.57 & 1 & 3.57 \\
\hline 6 & $781-925$ & 0 & 0 & 1 & 3.57 \\
\hline \multicolumn{2}{|c|}{ Total } & 28 & 100 & 28 & 100 \\
\hline
\end{tabular}

As seen in Table 5, prior to land acquisition, there are 78.5 percent households whose residential area is no more than $345 \mathrm{~m}^{2}$. After land acquisition, number of households with residential area of more than $345 \mathrm{~m}^{2}$ is almost doubled. In fact, there are 5 household whose residence is categorized as semi-permanent before land acquisition took place. After they received compensation, all household have permanent residence with adequate living facilities. So, instead of spending the received compensation on investment purposes such as buying a new farmland or kiosk, most households use it for consumption purposes like house makeover and renovation.

\section{Change In Household Prosperity}

Our next objective of this study is to investigate whether households are becoming more prosperous after receiving compensation. As already mentioned, we use ratio of household income per capita to regional decent standard of living or $\mathrm{KHL}$ to determine household prosperity. Our result is summarized at Table 6. From the data in Table 6, we can see during initial first stage land acquisition in 2006, Household in Gambarsari Village were categorized as prosper where household per capita income ratio 
to Regional KHL is larger than one. However, in 2016 which marked the second stage of land acquisition, the household prosperity of the people has already declined where they were categorized as less-prosperous household.

These data must be interpreted with caution because the lower prosperity condition of household in Gambarsari village during 2016 is not caused by land acquisition. As seen on the table, Household average income is much higher in 2016 compare to 2006. What makes people in Gambarsari Village less prosperous is the increase of KHL in Banyumas Regency. In 2006, regional KHL is set for Rp609,803 and ten years later it soars to Rp1,336,821. So, prior to land acquisition, on average the household prosperity condition in Gambarsari Village was categorized as less-prosperous. This finding supports previous research conducted by Barirotuttaqiyyah et. al. (2020) who also find that the infrastructure construction project has negative impact on prosperity. The comparison of household prosperity condition can be seen at Table 7 .

Table 6. Ratio of Household Income percapita to KHL

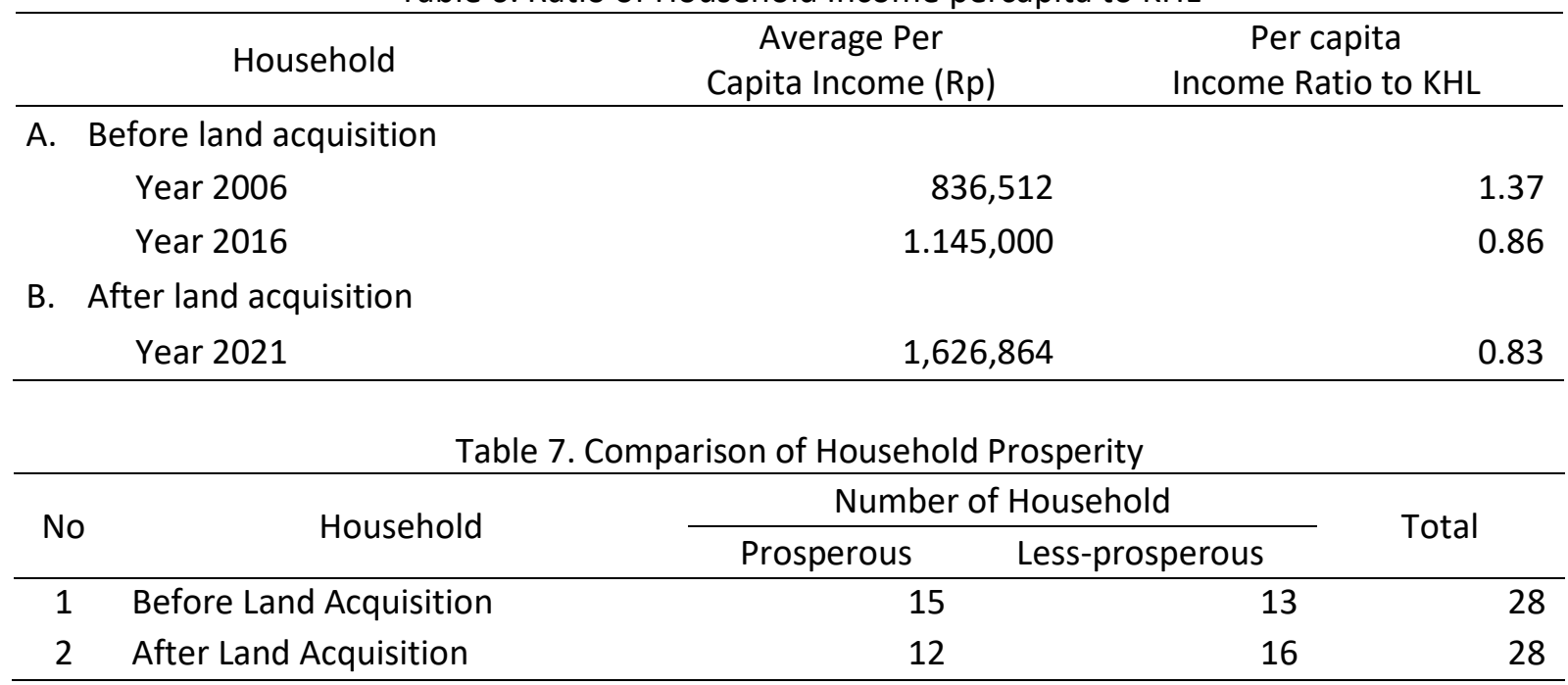

It is apparent from the Table 7 that after land acquisition the household prosperity declines. Before acquisition of land, there are 15 household who are categorized prosperous which means their average income is larger than regional decent standard of living. After they gave up their land and receive compensation, the number of households who are categorized as less-prosperous increase from 13 to 16 households.

Table 8. Distribution of Household Heads by Age

\begin{tabular}{ccc}
\hline Age Group (Years) & Number of Household & Percentage (\%) \\
\hline $48-54$ & 10 & 35.71 \\
$55-61$ & 4 & 14.29 \\
$62-68$ & 8 & 28.57 \\
$69-75$ & 4 & 14.29 \\
$76-82$ & 1 & 3.57 \\
$83-90$ & 1 & 3.57 \\
\hline
\end{tabular}

First possible explanation to this result is the fact that most of affected household in Gambarsari Village are elderly people who prefer to spend the compensated money for consumption rather than on new income generating asset. Second, half of the heads of households in Gambarsari Village apparently are no longer in productive age. As seen in Table 8, number of head of household whose are currently not in productive age are 14 . When our respondents were asked about whether they receive money from family or relative, 50 percent of them answer that they receive particular amount 
of money from their children and relatives. It may be the reason that the compensated money is used for consumption.

\section{CONCLUSIONS}

The main aim of this study is to investigate the implication of overpass and double line railway construction conducted by PT Kereta Api Indonesia (KAI) on changes in income generating asset and the level of welfare in the household in Gambarsari Village. This study shows that monetary compensation given by PT KAI has no significant impact on income generating asset on household. Another finding is that there is no significant increase in household welfare level after the monetary compensation was given. Most of the affected households in Gambarsari Village are elderly people who prefer to spend the compensated money for consumption rather than on new income generating asset.

Taken together, these findings suggest several courses of action and recommendation for people and related government agencies during land acquisition for project. For instance, PT. KAI and related government agencies need to conduct socialization and counseling on household financial management. So, compensation received by household whose land were evicted by government is used for productive purposes.

\section{REFERENCES}

Barirotuttaqiyyah, D., Mutaali, L., \& Kurniawan, A. (2020). Variasi Spasial Dampak Pembangunan Jalan Tol Terhadap Tingkat Kesejahteraan Petani Desa Koripan Kecamatan Susukan Kabupaten Semarang. Jurnal Widya Laksana, 9(1), 11-18. DOI: 10.23887/jwl.v9i1.18317.

Dewitasari, T. (2016). Dampak Pembangunan Jaln Tol Surabaya-Mojokerto Terhadap Kondisi Sosial dan Ekonomi Penduduk Di Daerah Kecamatan Wringinanom Kabupaten Gresik. Swara Bhumi eJournal Pendidikan Geografi FIS Unesa, 1(1), 197-207.

Ghozali, I. (2016). Aplikasi Analisis Multivariete Dengan Program SPSS. Semarang: Badan Penerbit Undip.

Kayupa, O. (2015). Dampak Sebelum dan Sesudah Pembangunan Pembangkit Listrik Tenaga Air (PLTA) Terhadap Kondisi Sosial dan Ekonomi Masyarakat di Desa Sulewana Kecamatan Pamona Utara Kabupaten Poso. EJournal Katalogis , 4(11), 217-227.

Kemenhub. (2018). Statistik Perhubungan 2018. Jakarta: Pustikom Kemenhub. Retrieved from http://dephub.go.id/ppid/informasi/. Acessed on 2021, March 25.

Kemenhub. (2019). Statistik Perhubungan 2019. Jakarta: Pustikom Kemenhub. Retrieved from http://dephub.go.id/ppid/informasi/. Accessed on 2021, March 25.

Matufany, Istiqomah, Kadarwati, N., Purnomo, S.D., 2021. The Impact of Airport Construction on Farm Households' Income. Jurnal Ekonomi dan Studi Pembangunan, 22(1), 1-11. DOI: 10.18196/jesp.v22i1.9206.

Nath, S., \& Raganata, G. (2020). An Assessment of Economic and Financial Impacts of Jakarta-Bandung High-Speed Railway Project. Journal of Business and Political Economy: Biannual Review of The Indonesian Economy, 2(1), 45-55.

Nguyen, T. T., Hegedűs, G., \& Nguyen, T. L. (2019). Effect of land acquisition and compensation on the livelihoods of people in Quang Ninh District, Quang Binh Province: Labor and income. Land, 8(6), 91, 1-10.

Obidzinski, K., Andriani, R., Komarudin, H., \& Andrianto, A. (2012). Environmental and social impacts of oil palm plantations and their implications for biofuel production in Indonesia. Ecology and Society, 17(1), 25-44.

Rianto, N. (2011). Indikator Perubahan Kesejahteraan Masyarakat Pasca Pembebasan Lahan Untuk Pembangunan Infrastruktur Pekerjaan Umum dan Pemukiman. Jurnal Sosek Pekerjaan Umum , 3(3), 185-194.

Rizal, A., Rosidah, \& Fathira, G. (2018). Potret Tingkat Kesejahteraan Rumah Tangga Pembudidaya Ikan di Ciganjur Jakarta Selatan. Jurnal IImu-IImu Sosial dan Humaniora, 1, 39-44. DOI: 10.24198/sosiohumaniora.v20i1.14401. 
Shankar, Devika. (2018). Contested land and contentious lines: Land acquisition for the railways in the late nineteenth and early twentieth-century Delhi. The Indian Economic and Social History Review, 55(4), 491-513.

Silondae, S., Aziz, A., \& Ernawati. (2016). Keterkaitan Jalur Transportasi dan Interaksi Ekonomi Kabupaten Konawe Utara Dengan Kabupaten/Kota Sekitarnya. Jurnal Progres Ekonomi Pembangunan, 1(1), 49-64. DOI: 10.33772/jpeb.v1i1.871.

Sugiyono. (2017). Metode Penelitian Kuantitatif. Yogyakarta: Alfabeta.

Tabachnick, B. G., Fidell, L. S., \& Ullman, J. B. (2014). Using multivariate statistics, $6^{\text {th }}$ edition. Boston, MA: Pearson New International Edition.

Wang, D., Qian, W., \& Guo, X. (2019). Gains and losses: Does farmland acquisition harm farmers' welfare? Land Use Policy, 86, 78-90. DOI:10.1016/j.landusepol.2019.04.037.

Wauran, P. (2012). Strategi Pemberdayaan Sektor Informal di Kota Manado. Jurnal Pembangunan Dan Keuangan Daerah, 7(3), 131-149.

Yughi, S. A. (2018). Analisis Tngkat Efisiensi Ekonomi Dan Kesejahteraan Usaha Tani Kangkung Darat dan Air Di Kecamatan Tambak Kabupaten Banyumas. Jurnal Akrab Juara , 3(4), 22-37. 